\title{
Cervical Cancer cT2b TNM Finding v8
}

National Cancer Institute

\section{Source}

National Cancer Institute. Cervical Cancer CT2b TNM Finding v8. NCI Thesaurus. Code C139698.

Cervical carcinoma invading beyond the uterus but not to the pelvic wall or to lower third of vagina with parametrial invasion. (from AJCC 8th Ed.) 